the bar, while a tension is induced at an early stage by the special design of the end conditions.

Section 5, which represents the first report of the Moulding Materials Sub-Committeo and extends to something like 120 pages, is a remarkable achievement for the time this Committee has been at work, and certainly represents the most important contribution yet made to the scientific and technological study of moulding sands for steel castings.

The report ends with a bibliography of some ninety pages dealing with the manufacture, properties and testing of steel castings, prepared by the Library and Information Department of the Institute. To all who have been in any way concerned with the work for, and the preparation of this report, wholehearted congratulations may be offered.

\section{Economic Policy in the Twentieth Century}

\begin{abstract}
A BROADSHEET, "Twentieth Century Economic A Policy", recently issued by P E P (Political and Economic Planning), directs attention to the need for guiding patterns to replace the one-sided patterns of laissez-faire and nationalism. The broadsheet largely summarizes the attempt to provide the essentials of such a pattern which are set forth in a memorandum prepared by Prof. N. F. Hall, director of the National Institute of Economic and Social Research. Measures adopted to maintain the volume of employment have checked improvements in the standard of living and new policies are required to raise the several national standards of living without in the process setting up intolerable strains. Recent scientific advances, moreover, justify the assumption that there is a minimum physiological standard of living which can be roughly measured and which is a necessary condition of progress in other directions. The satisfaction of minimum physiological neods can be set as an immediate goal for economic policies without sacrificing other values provided the methods adopted do not infringe individual freedom.
\end{abstract}

Economic adjustment demands increasing efficioncy in the older lines of production to liberate resources and particularly labour for new enterprises. The standards now available for nutrition supply a definite basis for assessing advances and setbacks as regards food. Less exactly approximate minimum standards can be ascertained for clothing, house space, and oquipment necessary for physiological well-being under different conditions of climate, etc. The first step towards stable national and international progress is therefore to draw up common standards of a broad and simple character and survey the deficiencies of different countries and regions. Not only is it becoming possible to determine such ininimum standards but also to forecast the actual demand for the various products in given conditions of price, income and knowledge. The key to expansion of demand lies in the relation between money incomes of consumers and the unit prices of basic necessities, which determine how much purchasing power will be available to raise consumption of all classes of goods above the level necessary for mere survival.

The cardinal aim of economic policy should thus be to reduce costs and prices of necessities, setting free margins of purchasing power which will in turn lead to reductions in the price of semi-luxuries.

\section{Science News a Century Ago}

The Statistical Society and Vital Statistics

IN the annual report of the Council of the Statistical Socisty, read at the anniversary myeting on March 15, 1839, it was stated that the Committee on Vital Statistics was still engaged in collecting data from which may be deduced the laws of human mortality. With regard to a collection of the experience of the numerous insurance societies, the circulation of the Committee's forms among the several offices had had the effect of inducing a committee of actuaries to renew the prosecution of a previously contemplated plan for collecting the desired information. Such a committee obviously possesses peculiar facilities for the task, the roport said, and as the Council had recoived the strongest assurance that the actuaries had the same object in view as the Society, to which they had promised to communicate the results of their labours, the proposed inquiry had been abandoned. But the Council had received some valuable returns from various medical establishments in reference to the subject, and the forms of registry suggested by the Council had been adopted in important public institutions.

\section{Stephen Peter Rigaud, F.R.S.}

ON March 16, 1839, the Oxford astronomer Stephen Peter Rigaud died at the house of his friend Benjamin Lewis Vulliamy, the clockmaker, in Pall Mall, Isondon. Descended from a family of French Protestant refugees, he was born in Richmond, Surrey, on August 12, 1774, his father being Stephen Rigaud (d. 1814), who for many years assisted the Rev. Stephen Demainbray at the King's Observatory at Kew. In 1791, at the age of seventeen years, Rigaud entered Exeter College, Oxford, and he spent practically all the rest of his life at the University. Graduating in 1797, ho became a fellow of the College, a tutor and examiner. In 1810 he succeeded Abraham Robertson in the Savilian chair of geo. motry and was again Robertson's successor in 1827 in the Savilian chair of astronomy, and this he held until his death. Described as "a laborious student, widely read, no mean conversationalist and a copious correspondent", he is remembered for his work as a mathematical antiquary and bibliographer.

\section{The Polypi of the Mediterranean}

"THE observations of M. Milne-Edwards on the Polypi of the Mediterranean," said the Athenceum of March 16, 1839, "have induced him to conclude, that the horny cartilaginous or calcareous coverings which envelope them, far from being mere external crusts, without any organic connexion with the animals, which produce them, aro integrant parts of these beings, and consist of an organised tissue, the substance of which is mors or less charged with horny or calcaroous matter deposited in it; and the nutrition of which is effected by introsusception. Among all these animals there exists a tendency in their tegumentary and reproductive parts to become hard, and the degree of solidification which these parts attain is the only character by which zoologists can class them, as naked polypi, flexible polypi, etc."

Prof. Henri Milne-Edwards (1800-1885), who was the son of an Englishman, filled the chairs of entomology, zoology and physiology at the Jardin des Plantes, Paris. 